\title{
An Empirical Examination Of Pension Rate Estimates: A Benchmark Approach
}

Alan I. Blankley, University of North Carolina at Charlotte, USA

Philip G. Cottell, Miami University, USA

David Hurtt, Baylor University, USA

\begin{abstract}
In this paper, we analyze pension rate choices for a sample of 495 firms over the thirteen-year period from 1994-2006. In recent years, articles have appeared in business publications alleging abuse of the discretion afforded to management in setting pension rates, particularly the pension discount rate and expected rate of return on plan assets. We find that pension discount rate estimates and expected rate of return estimates generally comply with the authoritative requirements, although there appears to be a smoothing effect in setting pension discount rates as well as a lag in fully reflecting economic conditions. We find evidence consistent with discount rate choice being influenced by deteriorating economic conditions, and possibly passage of the Sarbanes-Oxley Act. We also find that, in general, firms' expected rate of return assumptions tend to reflect their long-run internal rates of return on pension assets, although the recessionary influences in the early 2000s were not fully reflected in the expected rates of return toward the end of our test period. There is also a sizeable minority of firms (approximately 27\%) for which their expected rates of return on plan assets consistently overstate their actual, long-run returns.
\end{abstract}

Keywords: accounting, pensions, pension expected rate of return, pension discount rate

\section{INTRODUCTION}

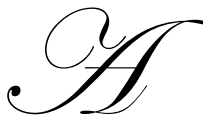

bout fifteen years ago, several articles alleging a crisis in defined benefit pension plan accounting and funding appeared in the popular business press. The articles suggested that aggressive pension rate assumptions using overly optimistic rate of return estimates and high discount rates allowed firms to manage earnings upward and minimize cash contributions to their plans (see Anders 1992, Pulliam 1993a and b, Alster 1993, and Light 1993). Those articles were written in an economic environment of comparatively high, but declining, interest rates and stagnating equity markets.

Over the past several years, similar articles have reappeared in the popular business press. The general theme of these articles is that some firms masked poor performance in their core operations throughout the 1990s by reporting large amounts of pension income, and this situation would likely reverse in an economic environment characterized by low interest rates and modest stock returns. ${ }^{1}$ In general, the authors claimed that many firms were setting, or keeping, their actuarial rate assumptions too high, which had the effect of reducing pension liabilities and decreasing pension cost. Artificially high rate assumptions, in turn, not only reduced the quality of reported earnings, but could lead to dramatic performance declines if firms had to lower them during an economic downturn.

The early 2000s witnessed just such a downturn. For example, after staying above $7 \%$ for most of the 1990s, Aa corporate bond rates fell to less than $5.0 \%$ by mid-2005. ${ }^{2}$ In addition, corporate profits increased from

\footnotetext{
${ }^{1}$ For examples of these sorts of articles, see Solomon and Hawkins (2005), Schultz and Francis (2004), Bulkeley (2002), Krantz (2002), Laise (2002), Brown and Weil (2001) and Buffet (2001).

${ }^{2}$ The annual average Corporate Aa rate was $6.23 \%$ in 2000 and reached its lowest average in 2005 at $5.35 \%$. Twenty-year Treasury bond yields mirrored the decline in corporate rates, only the decline ranged from an annual average of $6.23 \%$ in 2000 to a low of $4.64 \%$ in 2005. Both Corporate and Treasury rates increased in 2006.
} 
1994-2000, then fell roughly $35 \%$ by 2003 as a result of recessionary pressures. ${ }^{3}$ Even more importantly, stock prices fell by nearly $31 \%$ between 2000 and 2003, directly reducing pension plan assets. ${ }^{4}$ Given the increased pension liabilities attributable to interest rate declines and reduced pension assets due to stock market declines, the Pension Benefit Guaranty Corporation's (PBGC) programs for single-employer plans and multiemployer plans reversed from surpluses in 2001 to significant deficits by $2004 .^{5}$

Given the deterioration in economic conditions affecting pension assumptions over the first half of this decade, as well as the concerns raised by the popular press that pension rates were being maintained at an artificially high level, it seems reasonable to undertake a longitudinal, empirical examination of firms' pension rate choices. If firms were systematically overstating their pension rate choices, then the reported rates would appear to be significantly different from benchmarks, and changes in rates would lag changes in benchmarks or would fail to reflect the magnitudes of changes in benchmarks.

The FASB (2006) underscored the importance of this issue in Statement of Financial Accounting Standard (SFAS) No. 158, Employers' Accounting for Defined Benefit Pension and Other Postretirement Plans, which requires firms to recognize the net funded status - the fair value of pension plan assets less the projected benefit obligation (PBO) - on the balance sheet. SFAS no. 158 also requires gains and losses arising during the period that are not already recognized in net periodic pension cost to be recognized as a component of other comprehensive income. These gains and losses are attributable, at least in part, to gains and losses arising from changes in pension rate estimates. In addition, SFAS 158 stated that the board plans to comprehensively reconsider how to measure an employer's benefit obligation during the second, multi-year phase of its pension project. An important element of considering any changes in the measurement of pension liabilities would likely be information on the nature of the discount rates currently used to determine liability amounts as well as the nature of management's compliance in setting those rates and expected rates of return with the extant authoritative guidance.

In this paper, we analyze the pension rate estimates used between 1994 and 2006 in accounting for defined benefit plans. We compare the rates used by a sample of 495 companies to benchmark rates, in order to ascertain the degree of compliance with the guidance provided by Statement of Financial Accounting Standards (SFAS) 87, 106 and $132 \mathrm{R}$.

In response to the earlier allegations in the business press, Blankley and Swanson (1995) similarly studied the pension rate estimates used for a sample of 350 firms between 1987-1993. This paper complements and extends Blankley and Swanson (1995) in several ways:

(1) Like that study, we examine pension rate choices in response to allegations of impropriety. The recurrence of these allegations motivates an updated empirical evaluation of pension rate choices. In addition, significant pension legislation passed in 1994 (the Retirement Protection Act of 1994), which focused particular attention on the discount rates used for funding purposes. Whatever influence this legislation may have had on pension rate estimates for accounting purposes was not captured in the Blankley and Swanson time frame.

(2) Our research period represents an extended period of declining interest rates. With the exception of three years, the yields on high-quality (Aa) corporate bonds declined every year from 1994 to 2006 (except 1996, 1999, and 2006). By comparison, corporate bond rates declined by close to 300 basis points from the lowest point in the Blankley and Swanson time frame. This decline allows us to examine managers'

\footnotetext{
${ }^{3}$ In our sample, average net income declined from $\$ 306.1$ million in 2000 to $\$ 198.2$ million in 2002. By contrast, net income increased each year between 1994 and 2000 by an average of 13\%. In addition, the percentage of firms reporting losses more than doubled from $8 \%$ in 1994 to over $20 \%$ in 2002 . Underscoring the volatility, average net income in our sample increased by $107 \%$ to $\$ 410.5$ million between $2002-2004$, and the percentage of firms reporting losses declined by more than $50 \%$ to $9.1 \%$ over the same period.

${ }^{4}$ In December 1999, the Dow closed at 11,497.12. In February of 2003, its lowest point, the Dow closed at 7,891.08, a decline of approximately 31\%. In contrast, the Dow grew from 3,978.36 in January 1994 to 11,497.12 in December 1999, growth of $189 \%$.

5 The PBGC's single-employer program went from a surplus of approximately $\$ 6$ billion in 2001 to a deficit of approximately $\$ 21$ billion in 2004, while the multiemployer program went from a surplus of approximately \$150 million in 2002 to a deficit of over $\$ 300$ million in 2005 .
} 
compliance as benchmark rates approach historical lows. A protracted decline in rates may create pressure on management to resist lowering pension discount rates beneath an arbitrary "floor."

We examine the impact a combined decline in market returns and interest rates has on pension rate choices. Between 1994-2006, the market rose to historic levels and then suffered a dramatic downturn, followed by a recovery. ${ }^{6}$ The economic downturn created a difficult compliance environment, perhaps the most difficult environment since SFAS 87 was adopted. Just as the economy was entering recession, companies faced actuarial-driven increases in pension liabilities and pension expense, along with market declines in pension assets and returns. The combination threatened reported income and cash flows. ${ }^{7}$ These factors led us to investigate whether managers attempted to mitigate the situation by keeping pension rates unrealistically high.

We find that the percentage of firms adjusting their rate of return estimates in any year remains relatively stable from 1994-2001, ranging from 16\% to $20 \%$ of our sample. Firms increased their expected rate of return by an average of 19 basis points over this eight-year period. This average is surprisingly small, considering that 1994 to 2001 includes the 1990s market bubble. In contrast, during the 2002 and 2003 market declines, $46.3 \%$ and 37.5\%, respectively, of the sample firms adjusted their expected rates of return. The two-year decrease in average expected returns is 56 basis points, which is nearly three times the observed increase during the bubble years (1994-2001). Expected rates declined again in 2004, 2005, and 2006 by another 29 basis points, to 8.14\%, the lowest point in the test period. Even so, the average expected rates in 2002 were higher than the long-run, actual returns earned by firms' pension assets since 1994. Long-run, internal rates of return on pension assets recovered after 2002 and remained slightly above average expected returns through 2006.

Any justification for high expected rates of return based solely on historical evidence must be tempered by the distinct possibility that returns over the next decade are likely to be lower than those earned between 1994-2006. In its 2002 review of Fortune 500 companies, the Securities and Exchange Commission commented on the longterm expected return assumptions used, and requested that firms provide information about the basis and reasonableness of their expected rates of return (SEC 2003).

The percent of firms in our study that changed discount rates during any particular year ranges from a low of $61.2 \%$ in 1996 to a high of $91.5 \%$ in 2004. This represents a marked contrast from the Blankley and Swanson test period (1987-1993), where no more than 55.2\% of their sample changed rates in any period (except 1993). Frequent discount rate adjustments are consistent with the requirements of SFAS 87. Nevertheless, the magnitude of discount rate adjustments is nearly always less than corporate bond rate changes, suggesting that managers smooth the impact on the financials and pension disclosures. We also find that discount rates are especially "sticky" when corporate rates decline. With the exception of one year (2003-2004), we find that the spread between companies' discount rates and corporate benchmark rates increases in every year that corporate rates decline, while the spread declines in every year that corporate rates increase. We also find a strong negative correlation in all years between the change in corporate rates and the change in spreads between firms' discount rates and benchmark rates. These results are consistent with the notion that managers are less likely to fully reflect the impact of declining rates while more likely to fully reflect the impact of increasing rates. Rate declines increase pension liabilities and expense; rate increases have the opposite effect. This finding suggests that as corporate rates reached historic lows, managers were reluctant to set discount rates that fully reflected benchmark rates.

\footnotetext{
${ }^{6}$ Examining the DJI from 1987-1993 reveals that the index rose steadily over that time frame, with a 1-year decline of approximately 16\% during the 1990-91 period. By contrast, the 1994-2000 period saw the index increase from approximately 4,000 to 11,500, after which there was a 3 -year decline of close to $34 \%$. The magnitude and duration of the market's decline between 2000 and 2002 exceeded those in the early 90s, having, we believe, greater potential to affect managers' pension rate choices because of the effect on plan assets.

${ }^{7}$ A quote from Gannet Company's 2001 10K illustrates the potential cash flow impact: “During 2001, the company's retirement plan assets declined in market value.... As a result of this investment performance, and the use of a lower discount rate to value plan liabilities at the end of 2001, total retirement plan obligations grew to exceed plan assets. To reduce this under-funding, the company made a $\$ 300$ million tax-deductible contribution to the plan in December 2001, and may consider making additional contributions in 2002."
} 
Finally, with the exception of the $2002-2004$ period, more firms adjusted their salary progression rates each year than adjusted their expected rates of return. The percentage of firms changing their future salary expectation ranges from a low of $20 \%$ in 2000 to a high of $41.2 \%$ in both $1994 \& 2002$. Firms reduced their anticipated future salary increases over the test period from, on average, $5.06 \%$ to $4.1 \%$ by 2006 . Given that the PBO and pension expense both decrease with declines in estimated salary rates, the salary decline may be an attempt to offset the effect of lower discount rates. Alternatively, the declines may reflect the fact that lower inflation expectations influence each rate.

The next section of this paper overviews the guidance in the authoritative literature for choosing pension rates. Following that, we discuss our sample selection and data gathering procedures, and provide descriptive evidence concerning the discount rate, expected rate of return, and salary progression rate. Next, we provide a more in-depth analysis of managers' discount rate choices and analyze the expected rate of return. We end with a summary and some comments about our findings.

\section{AUTHORITATIVE GUIDANCE ON PENSION RATES}

One of the FASB's objectives in issuing SFAS 87 was to reduce the range of choices for allocating the cost of pension benefits across reporting periods. As such, the Board limited the actuarial attribution method allowable for expense recognition, settling on a benefits attribution approach, but left discretion over certain assumptions to management in order to reflect differing circumstances among firms. In this way, while a single actuarial cost attribution method was required, flexibility was allowed so managers could reflect firm-specific circumstances in their pension rates. However, the Board did require all rate estimates be best estimates with respect to that particular rate. This requirement reflects an explicit approach to determining the rates (paragraph 191); in contrast, in an implicit approach, one rate would offset the effect of another rate so that the net result of the combination of rates represents a good estimate, but individual rate estimates may not be particularly good estimates. The Board also delineated criteria for three rates used in making pension estimates: discount rate, expected rate of return, and expected rate of future compensation.

\section{Discount Rate}

In SFAS 87, the Board required that the rate used to discount pension liabilities and determine the service cost and interest cost components of pension expense reflect a settlement rate--the rate at which those benefits could be effectively settled. ${ }^{8}$ In order to determine appropriate settlement rates, firms may "look to rates of return on highquality fixed income investments currently available and expected to be available during the period to maturity of the pension benefits" (paragraph 44). SFAS 106 clarified this notion by identifying as the theoretically preferred discount rate the yield on a portfolio of high-quality, zero coupon bonds whose maturity dates and payment amounts equal expected cash outflows for the firm's accumulated postretirement benefit obligation. When zero coupon bonds are not used, the discount rates need to incorporate expected reinvestment rates available in the future (paragraph 186). Conceptually, the rate should reflect the single sum that, if invested at the measurement date, would yield the cash necessary to pay the benefits when they become due, or if settlement with a third-party insurer is possible, the rate inherent in the amounts at which the obligation could be settled. The Board also noted that discount rates should be re-evaluated at each measurement date and, as interest rates rise or decline, discount rates should change in a similar manner (paragraph 187). More recently, in an effort to clarify for firms how to determine appropriate discount rates, the SEC pointed to the guidance provided in EITF Topic D-36, which identified a hypothetical portfolio of high-quality bonds rated Aa or higher for which the timing and amount of future cash flows approximate the payments from the pension plan.

\footnotetext{
${ }^{8}$ A company could settle its benefits by (a) making lump-sum cash payments to plan participants in exchange for their rights to receive specified pension benefits, or by (b) purchasing nonparticipating annuity contracts to cover vested benefits (SFAS 87). The FASB clarified the notion of "effectively settled" in SFAS. 106 by stating that "effectively settled" considered only the time value of money, and not the insurer's risk inherent in the rate.
} 


\section{Expected Rate of Return}

The expected rate of return on plan assets is required to be a long-term rate that reflects the average rate of earnings on funds invested to provide for the benefits included in the projected benefit obligation. In estimating this rate, management is required to consider both the returns being earned by the plan assets and the rate of return expected to be available in the future (SFAS 87, paragraph 46). In other words, the rate is to be a firm-specific blend of both past returns and future expectations. There is no requirement that this rate adjust to exogenous interest rates (as there is for the discount rate), nor is there any particular guidance for evaluating "future expectations" other than that this rate reflects the long-term. In practice, changes in this rate should be infrequent and moderate, and should have a basis in the composition of the pension assets and/or changes in long-term interest rates. In support of this basis, Amir \& Benartzi (1998) found a weak correlation between the expected returns and asset composition.

SFAS 132R requires companies to disclose the basis for their expected rate of return assumptions. For example, the Coca-Cola Company's 2005 10-K states that the expected rate of return assumption is "based upon ... target asset allocation and is determined using forward-looking assumptions in the context of historical returns and volatilities for each asset class, as well as correlations among asset classes" (Coca-Cola 2005).

\section{Expected Rate of Future Compensation}

The expected rate of future compensation, or salary progression rate, applies only to plans that use future salary levels in their pension benefit formula. These firm-specific rates are supposed to represent management's estimate of the actual future compensation levels of the individuals covered by the plan. In determining the rate, management should consider future changes due to general price levels, productivity, seniority, promotions, and other factors that influence an individual's compensation. Finally, SFAS 106 notes that all assumptions should be consistent to the extent that they include estimates of the same influences, like inflation (SFAS 106, paragraph 33).

\section{SAMPLE SELECTION AND DESCRIPTIVE STATISTICS}

To select our sample, we screened Compustat for all firms reporting amounts for discount rates, plan assets, and projected benefit obligations. We then supplemented the Compustat data collected with data from firms' $10-\mathrm{K}$ filings using DirectEdgar and Bloomberg Data Services in order to obtain information that was unavailable, missing or incomplete from Compustat (for example, the firms' actual return on plan assets was missing for most of the years before 2000). The final sample includes 495 firms with relatively comprehensive pension data for the test period 1994-2006. The number of firms used in any particular analysis differs from 495, depending on the variables examined and the year, due to missing data items and the natural attrition of the sample over such an extended time period as a result of firm failures and acquisitions.

Figure 1 (Panel A) charts the average expected rates of return, discount rates, and salary progression rates for each year from 1994 through 2004. Panel B presents descriptive statistics for the three rates. One key question we considered was how companies adjusted return estimates during the 1990s market bubble and subsequent crash. ${ }^{9}$ Between 1994 and 2000, the S\&P 500 and Dow indices roughly doubled, while the NASDAQ increased six-fold. While the pension expected rate of return trended upward from 1994 to 2000, the total increase over this period was only $0.20 \%(9.00 \%-8.80 \%)$. During the crash, the mean rate fell by $0.32 \%$ in 2002 , by an additional $0.53 \%$ by 2006. The 2006 mean expected return of $8.14 \%$ is the lowest level since SFAS 87 became effective. The observable declines from 2003 - 2006 were likely influenced by the SEC's December 2002 public statement that it would review expected rates of return higher than $9 \%$ if the rate was not clearly justified in the company's financial report (GAO 2004), and reflect increased regulatory scrutiny of the rate. The SEC guidance helps explain the surprising finding that the resulting downward adjustment exceeded the increase during the 1990s bubble.

\footnotetext{
${ }^{9}$ The Dow topped out on January 14, 2000, at 11,722.98. Three months later, on March 10, the NASDAQ index reached its apogee: 5,048. Two weeks after that, the S\&P 500 hit its bull market high of 1,527.46 (Mahar 2004).
} 
Figure 1

Pension Rate Descriptive Statistics by Year

Panel A: Chart of Mean Pension Rates by Year

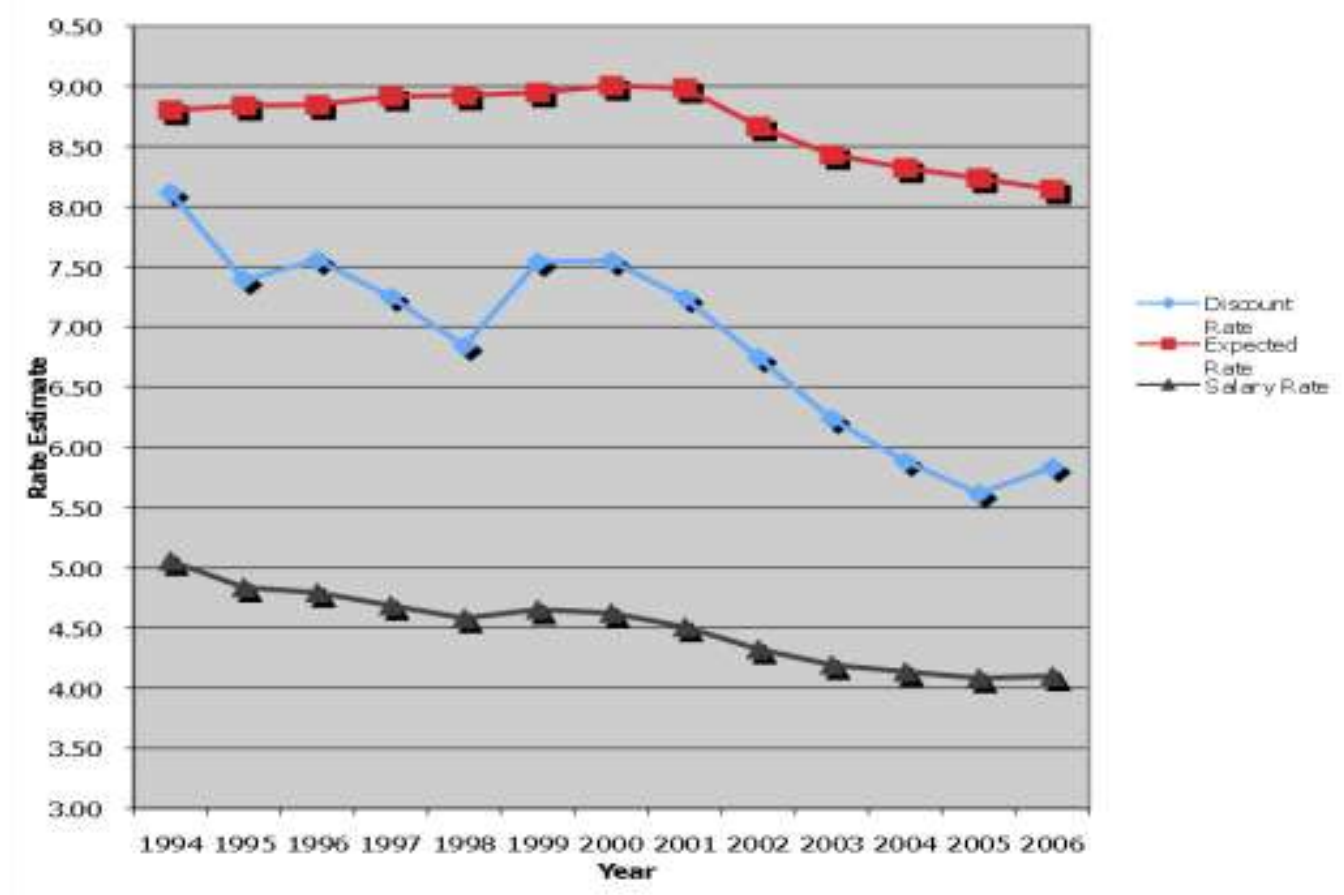

Panel B: Pension Rate Descriptive Statistics

\begin{tabular}{|c|c|c|c|c|c|c|c|c|c|c|c|c|c|}
\hline Discount Rate & 1994 & 1995 & 1996 & 1997 & 1998 & 1999 & 2000 & 2001 & 2002 & 2003 & 2004 & 2005 & 2006 \\
\hline Mean & 8.12 & 7.39 & 7.56 & 7.25 & 6.84 & 7.54 & 7.55 & 7.24 & 6.75 & 6.24 & 5.88 & 5.62 & 5.83 \\
\hline Min & 6 & 6 & 6 & 6 & 5.5 & 6 & 6 & 5.5 & 4.75 & 5 & 5 & 4.5 & 3.63 \\
\hline Max & 9.75 & 9 & 8.5 & 8.3 & 8 & 8.5 & 8.3 & 8 & 8 & 8 & 8 & 8 & 8 \\
\hline Median & 8.25 & 7.3 & 7.5 & 7.25 & 6.75 & 7.5 & 7.5 & 7.25 & 6.75 & 6.25 & 5.84 & 5.61 & 5.85 \\
\hline Std Dev & 0.530 & 0.405 & 0.327 & 0.301 & 0.319 & 0.422 & 0.343 & 0.290 & 0.331 & 0.311 & 0.254 & 0.272 & 0.291 \\
\hline $\mathrm{N}$ & 495 & 495 & 495 & 495 & 495 & 495 & 495 & 495 & 496 & 488 & 430 & 426 & 386 \\
\hline Expected Rate & 1994 & 1995 & 1996 & 1997 & 1998 & 1999 & 2000 & 2001 & 2002 & 2003 & 2004 & 2005 & 2006 \\
\hline Mean & 8.8 & 8.84 & 8.85 & 8.92 & 8.92 & 8.95 & 9.00 & 8.99 & 8.67 & 8.43 & 8.32 & 8.23 & 8.14 \\
\hline Min & 6 & 5 & 1.025 & 6 & 4.5 & 4.5 & 4.5 & 6 & 5 & 5 & 5 & 2 & 2 \\
\hline Max & 13 & 11 & 11 & 11.2 & 11 & 11 & 11 & 11 & 11 & 10.4 & 10 & 10 & 10 \\
\hline Median & 9 & 9 & 9 & 9 & 9 & 9 & 9 & 9 & 8.75 & 8.5 & 8.5 & 8.5 & 8.25 \\
\hline stdev & 0.82 & 0.81 & 0.84 & 0.79 & 0.86 & 0.85 & 0.81 & 0.79 & 0.76 & 0.68 & 0.64 & 0.72 & 0.8 \\
\hline $\mathrm{N}$ & 495 & 495 & 495 & 495 & 494 & 495 & 495 & 495 & 496 & 483 & 452 & 426 & 390 \\
\hline Salary Rate & 1994 & 1995 & 1996 & 1997 & 1998 & 1999 & 2000 & 2001 & 2002 & 2003 & 2004 & 2005 & 2006 \\
\hline Mean & 5.06 & 4.84 & 4.79 & 4.68 & 4.58 & 4.65 & 4.62 & 4.51 & 4.32 & 4.19 & 4.13 & 4.08 & 4.1 \\
\hline Min & 2.5 & 2.5 & 3 & 1.3 & 1.5 & 0 & 0 & 0 & 0 & 0 & -1.28 & 0 & 0 \\
\hline Max & 8.5 & 15 & 8 & 8 & 9 & 9 & 9.5 & 6.5 & 6.3 & 6.3 & 6.125 & 6 & 9 \\
\hline Median & 5 & 5 & 5 & 4.75 & 4.5 & 4.75 & 4.5 & 4.5 & 4.25 & 4 & 4 & 4 & 4 \\
\hline stdev & 0.74 & 0.86 & 0.69 & 0.69 & 0.73 & 0.72 & 0.71 & 0.66 & 0.66 & 0.69 & 0.71 & 0.72 & 0.84 \\
\hline $\mathrm{N}$ & 495 & 495 & 494 & 495 & 495 & 495 & 495 & 495 & 496 & 477 & 418 & 410 & 362 \\
\hline
\end{tabular}


Figure 1 also shows that the salary progression rate and the discount rate follow a basic downward trend, consistent with both rates reflecting declining inflation expectations, but the trend for the discount rate is significantly more volatile. In fact, the discount rate is the most volatile of the three rates, reflecting the SFAS 87 requirement to adjust the rate at each annual measurement date to reflect changes in benchmark rates. Over the 13year time period, the average discount rate fell from a high of $8.12 \%$ in 1994 to a low of 5.62\% in 2005, a downward adjustment of 250 basis points.

Table 1 presents information about the frequency and magnitude of rate changes. Panel A indicates that, of the three rates, only the discount rate is changed by most firms each year. The percent of firms changing discount rates ranges from lows of about $60 \%$ to a high of $91.5 \%$ in 2004. In fact, over $80 \%$ of our sample firms adjusted their discount rates in 9 of the 13 years studied. Note that this represents a marked shift from the Blankley and Swanson (1995) test period (1987-1993), where no more than 55.2\% of that sample changed rates in any year except 1993.

Table 1

Mean Rate Changes

\begin{tabular}{|c|c|c|c|c|c|c|c|c|c|}
\hline \multicolumn{10}{|c|}{ Panel A: Frequency and Magnitude of Rate Changes } \\
\hline \multirow{4}{*}{ Year } & \multicolumn{3}{|c|}{ Discount Rate Changes } & \multicolumn{3}{|c|}{ Expected Rate Changes } & \multicolumn{3}{|c|}{ Salary Rate Changes } \\
\hline & & $\%$ of & Mean & Num. of & $\%$ of & & Num. of & $\%$ of & \\
\hline & Num. of & Firms & Rate & Firms & Firms & Mean & Firms & Firms & Mean Rate \\
\hline & Firms Chg & Chg & Chg & Chg & Chg & Rate Chg & Chg & Chg & Chg \\
\hline $94-95$ & 417 & $85.1 \%$ & -.724 & 94 & $19.2 \%$ & .036 & 202 & $41.2 \%$ & -.217 \\
\hline $95-96$ & 300 & $61.2 \%$ & .166 & 89 & $18.2 \%$ & .007 & 118 & $24.1 \%$ & -.045 \\
\hline $96-97$ & 346 & $70.6 \%$ & -.306 & 89 & $18.2 \%$ & .073 & 132 & $27.0 \%$ & -.106 \\
\hline $97-98$ & 410 & $83.7 \%$ & -.399 & 101 & $20.2 \%$ & .007 & 161 & $32.9 \%$ & -.099 \\
\hline 98-99 & 437 & $89.2 \%$ & .692 & 92 & $18.8 \%$ & .021 & 136 & $27.8 \%$ & .066 \\
\hline 99-00 & 305 & $62.2 \%$ & .007 & 79 & $16.1 \%$ & .057 & 98 & $20.0 \%$ & -.029 \\
\hline 00-01 & 402 & $82.0 \%$ & -.310 & 78 & $15.9 \%$ & -.019 & 140 & $28.6 \%$ & -.117 \\
\hline 01-02 & 444 & $90.6 \%$ & -.496 & 227 & $46.3 \%$ & -.316 & 202 & $41.2 \%$ & -.179 \\
\hline $02-03$ & 421 & $87.2 \%$ & -.510 & 179 & $37.5 \%$ & -.243 & 145 & $30.7 \%$ & -.144 \\
\hline 03-04 & 388 & $91.5 \%$ & -.352 & 134 & $30.4 \%$ & -.099 & 131 & $32.0 \%$ & -.052 \\
\hline 04-05 & 347 & $85.7 \%$ & -.268 & 110 & $26.1 \%$ & -.096 & 125 & $31.9 \%$ & -.045 \\
\hline 05-06 & 323 & $85.0 \%$ & .230 & 98 & $25.7 \%$ & -.097 & 105 & $29.7 \%$ & .031 \\
\hline
\end{tabular}

Panel B: Number (percent) of Firms Changing Rates by the Frequency of Their Rate Changes Over the 13 Years

\begin{tabular}{|c|c|c|c|c|c|c|}
\hline \multirow[t]{2}{*}{$\begin{array}{l}\text { Num of Rate } \\
\text { Changes }\end{array}$} & \multicolumn{2}{|c|}{ Discount Rate } & \multicolumn{2}{|c|}{ Expected Rate } & \multicolumn{2}{|c|}{ Salary Rate } \\
\hline & Num Firms & $\%$ Firms & Num Firms & $\%$ Firms & Num Firms & $\%$ Firms \\
\hline 0 & 2 & $0.41 \%$ & 52 & $10.59 \%$ & 52 & $10.59 \%$ \\
\hline 1 & 1 & $0.20 \%$ & 90 & $18.33 \%$ & 73 & $14.87 \%$ \\
\hline 2 & 7 & $1.42 \%$ & 111 & $22.61 \%$ & 92 & $18.74 \%$ \\
\hline 3 & 2 & $0.41 \%$ & 91 & $18.53 \%$ & 73 & $14.87 \%$ \\
\hline 4 & 7 & $1.42 \%$ & 58 & $11.81 \%$ & 62 & $12.63 \%$ \\
\hline 5 & 10 & $2.04 \%$ & 42 & $8.55 \%$ & 37 & $7.54 \%$ \\
\hline 6 & 29 & $5.91 \%$ & 17 & $3.46 \%$ & 24 & $4.89 \%$ \\
\hline 7 & 33 & $6.72 \%$ & 12 & $2.44 \%$ & 29 & $5.91 \%$ \\
\hline 8 & 61 & $12.42 \%$ & 9 & $1.83 \%$ & 28 & $5.70 \%$ \\
\hline 9 & 74 & $15.07 \%$ & 6 & $1.83 \%$ & 5 & $1.02 \%$ \\
\hline 10 & 99 & $20.16 \%$ & 2 & $0.41 \%$ & 9 & $1.83 \%$ \\
\hline 11 & 100 & $20.37 \%$ & 1 & $0.20 \%$ & 4 & $0.81 \%$ \\
\hline 12 & 66 & $13.44 \%$ & 0 & $0.00 \%$ & 3 & $0.61 \%$ \\
\hline
\end{tabular}

Panel B of Table 1 provides a distribution of the frequency of firms' rate changes. For the discount rate, we observe at the extremes that two firms $(0.41 \%)$ did not change their discount rates at all over the ten years studied. At the other extreme, 66 firms (13.44\%) changed their discount rates every year. And $81.5 \%$ of our sample firms adjusted discount rates eight or more times across the thirteen years. The data are consistent with greater compliance with the FAS 87 requirement to reflect the current interest rate environment at each measurement date. 
A striking result can be seen when examining the expected rate of return estimates on Panel A of Table 1: the number of firms adjusting their expected rate estimates more than doubles in 2001-2002 compared to earlier years, and the number of firms adjusting the expected rate in each of the ensuing years is, with one exception, higher than in any year prior to 2002. From 1994-2001, the percentage of firms adjusting their expected rates of return remains relatively stable, ranging from $15.1 \%$ to $20.2 \%$ of the sample. In 2002 , however, $46.3 \%$ of the sample adjusted the rate; in every subsequent year, more than $25 \%$ of the sample firms adjusted the rate. In spite of the increasing rate changes after 2001, there is also evidence that, in general, firms are reluctant to adjust their expected rates of return. Panel B of Table 1 indicates that $70 \%$ of our sample firms adjusted the estimate three times or less during the test period. We will examine the accuracy of the expected rate of return in more detail later.

Examining the direction of expected rate changes is informative as well. Mean rate adjustments from 19942000 were upward - firms were consistently raising their expected rate of return estimates during the 1990s market increases, although the increases were very small. ${ }^{10}$ Following such small changes, the last five years' consecutive declines represent a relatively large downward adjustment to $8.14 \%$ from $9 \%$. The timing of these rate declines reflects not only the economic pressure from declining equity markets at the time, but we also suspect that the SEC's stated intention in 2002 to examine expected rate of return assumptions more closely and, in addition, the greater regulatory scrutiny generated by the passage of the Sarbanes-Oxley Act in July 2002, contributed to the increasingly conservative expected rate assumptions we observe. ${ }^{11}$

Finally, with the exception of 2002-2004, more firms adjusted their salary progression rates each year than adjusted their expected rates of return. The percentage of firms changing their future salary rates ranges from a low of $20 \%$ in 2000 to a high of $41.2 \%$ in 1995 \& 2002. Since the change in every year except 1999 and 2006 is negative, the evidence indicates that firms systematically reduced their future salary expectations over the test period. Given that the PBO and pension expense both decrease with declines in estimated salary rates, the salary decline may represent an attempt to offset the effect of the discount rate declines. Alternatively, each rate may reflect declining inflation expectations. However, Panel B in Table 1 indicates that companies change this rate much less frequently than the discount rate. Seventy-two percent of our sample changed the rate four times or less during the time period, while only $28 \%$ changed it four times or more.

\section{ANALYSIS OF THE DISCOUNT RATE}

In order to evaluate firms' discount rate estimates, we selected benchmark rates based on the guidance provided in SFAS 87 and 106. Since it is impossible for us to construct hypothetical portfolios of high-quality, zero coupon bonds with maturities matching the dates at which benefits become due, we used the rates available on highquality corporate bonds at each company's pension information date as reported in Compustat. These rates are mentioned as appropriate in SFAS 106, and are used by actuaries and auditors in helping them to determine the

\footnotetext{
${ }^{10}$ The mean rate changes presented in Table 1 represent averages across our entire sample. For the expected rate of return and the salary rates, they understate the amounts by which rate-changing firms actually raised or lowered their rates because of the significant number of observations where the rate changes were zero. Discount rates are also affected, but less so due to the greater number of non-zero observations. The mean rate changes for firms that actually changed rates were as follows:

$\begin{array}{llll} & \text { Expected Rate } & \text { Salary Rate } & \text { Discount Rate } \\ 1995 & .19 & -.53 & -.85 \\ 1996 & .04 & -.18 & .26 \\ 1997 & .40 & -.39 & -.43 \\ 1998 & .04 & -.30 & -.48 \\ 1999 & .11 & .24 & .78 \\ 2000 & .35 & -.15 & .02 \\ 2001 & -.12 & -.41 & -.38 \\ 2002 & -.68 & -.43 & -.54 \\ 2003 & -.65 & -.47 & -.59 \\ 2004 & -.33 & -.16 & -.37 \\ 2005 & -.37 & -.14 & -.31 \\ 2006 & -.38 & .10 & .23\end{array}$

${ }^{11}$ By "increasingly conservative," we mean to imply that the rates were conservative relative to earlier rate assumptions, not that the rate assumptions were necessarily conservative in an absolute sense.
} 
range of acceptable discount rates complying with SFAS $87 .{ }^{12}$ In addition, the SEC has interpreted the requirement that firms use a settlement rate to mean that the discount rate should reflect the rates available on high-quality, fixedincome instruments with Aa ratings or higher, having similar durations to the company's pension liabilities (Deloitte 2003). The corporate bond rates we use are the daily rates on 20-year, Aa rated bonds from all industries compiled by Moody's, acquired from Bloomberg data services.

To get a broader perspective, we also use the contemporaneous daily 20-year Treasury bond rates available from the Federal Reserve, ${ }^{13}$ as well as the contemporaneous monthly rates published by the Pension Benefit Guaranty Corporation (PBGC). ${ }^{14}$ The PBGC "provides monthly updates of the interest rates affecting pension plans," and these rates, while considered overly conservative (Blankley and Swanson 1995), are nonetheless mentioned in SFAS 87 as a source of possible guidance concerning the discount rate. While none of the individual benchmarks represents the "ideal" benchmark, mainly because they do not incorporate information concerning the duration of individual plan liabilities, they do allow us to gauge where companies' discount rates fall relative to commonly used, and widely accepted, benchmark rates.

Figure 2

Chart of Discount Rates and Benchmark Rates by Year

\section{Panel A: Chart of Rates}

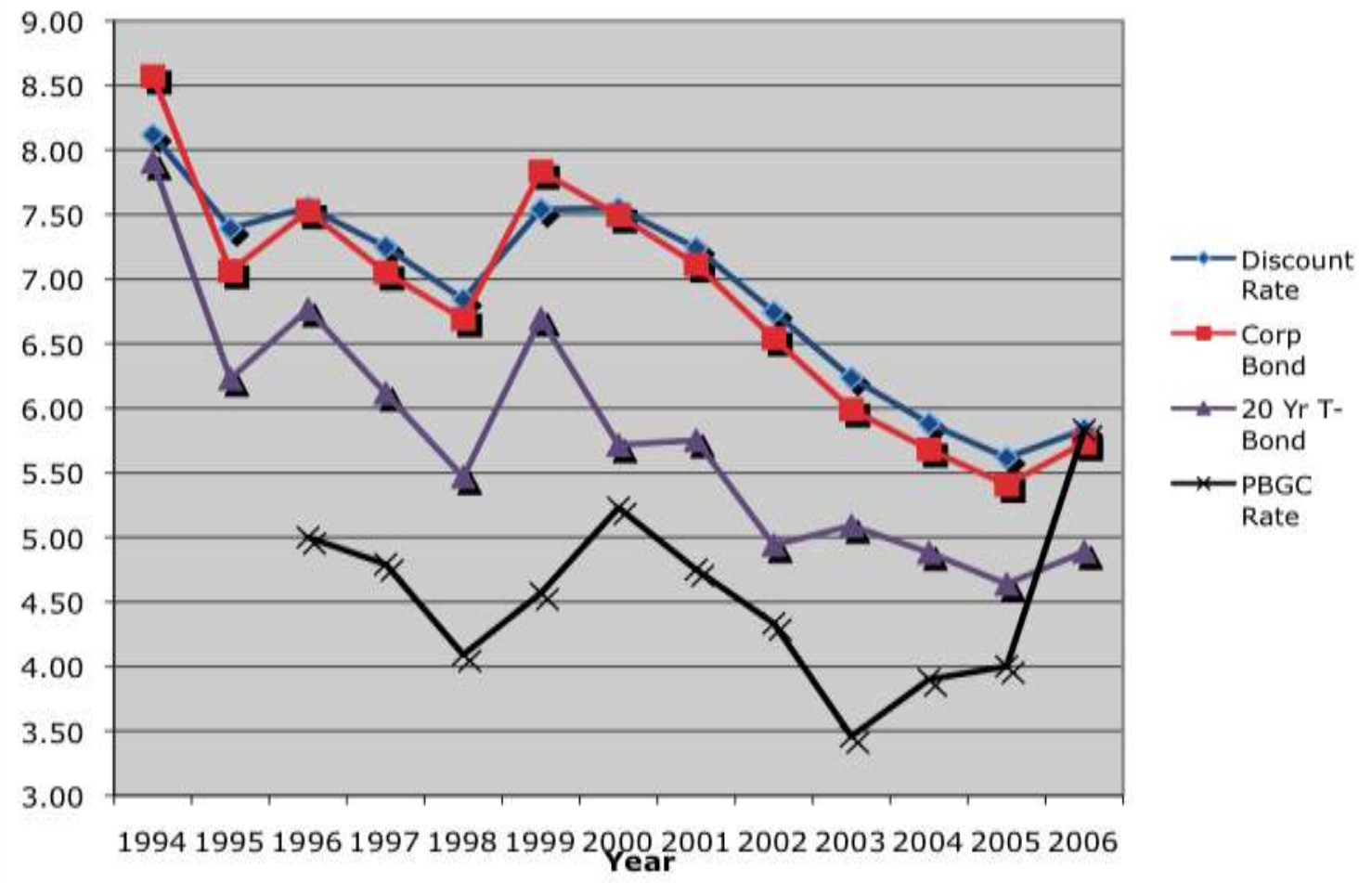

\footnotetext{
${ }^{12}$ See, for example, the 2003 survey of pension assumptions developed by Deloitte.

${ }^{13}$ It may be argued that 30-year Treasury bond rates are more appropriate, since those are the rates required by the Retirement Protection Act of 1994 (RPA 94) to be used in determining pension minimum funding amounts and the Deficit Reduction Contributions (DRC). While preferable from this perspective, the Federal government stopped issuing 30-year Treasury bonds in February 2002, a critical point in our analysis. Furthermore, 30-year Treasury bonds have a 99.09\% correlation with 20 -year bonds for the time period in our sample, with the 30-year rates always lower than 20 -year bonds. Thus, if the 20 -year Treasury bond rate is a biased estimator, it biases against finding differences between firm discount rates and benchmark rates because those differences are smaller.

${ }^{14}$ PBGC rates available on the PBGC's website only go back to 1996.
} 
Panel B: Table of Rates

\begin{tabular}{ccccc} 
Year & $\begin{array}{c}\text { Discount } \\
\text { Rate }\end{array}$ & $\begin{array}{c}\text { Corp } \\
\text { Bond }\end{array}$ & $\begin{array}{c}\text { 20 Yr } \\
\text { Treasuries }\end{array}$ & $\begin{array}{c}\text { PBGC } \\
\text { Rate }\end{array}$ \\
\hline 1994 & 8.12 & 8.57 & 7.91 & - \\
1995 & 7.39 & 7.06 & 6.23 & - \\
1996 & 7.56 & 7.53 & 6.77 & 5.00 \\
1997 & 7.25 & 7.05 & 6.12 & 4.79 \\
1998 & 6.84 & 6.69 & 5.47 & 4.09 \\
1999 & 7.54 & 7.83 & 6.69 & 4.57 \\
2000 & 7.55 & 7.49 & 5.71 & 5.23 \\
2001 & 7.24 & 7.11 & 5.75 & 4.75 \\
2002 & 6.75 & 6.54 & 4.94 & 4.33 \\
2003 & 6.24 & 5.99 & 5.09 & 3.46 \\
2004 & 5.88 & 5.68 & 4.88 & 3.90 \\
2005 & 5.62 & 5.41 & 4.64 & 4.00 \\
2006 & 5.83 & 5.73 & 4.89 & 5.83 \\
\hline
\end{tabular}

\section{Discount Rate Levels}

Figure 2 above (Panels A and B) presents the 1994-2006 mean discount rates along with rates from a highquality corporate bond portfolio, the 20-year Treasury bond, and the PBGC. The three benchmark rates do not always change in the same direction, but for all years, Treasury rates and PBGC rates are notably lower than corporate bond rates. Two observations about the discount rate are important: first, discount rates track most closely with corporate bond rates. Second, the discount rate is higher than corporate bond rates in all years except 1994 and 1999.

Figure 3

Analysis of Difference between Corporate Bond Rate and Discount Rate

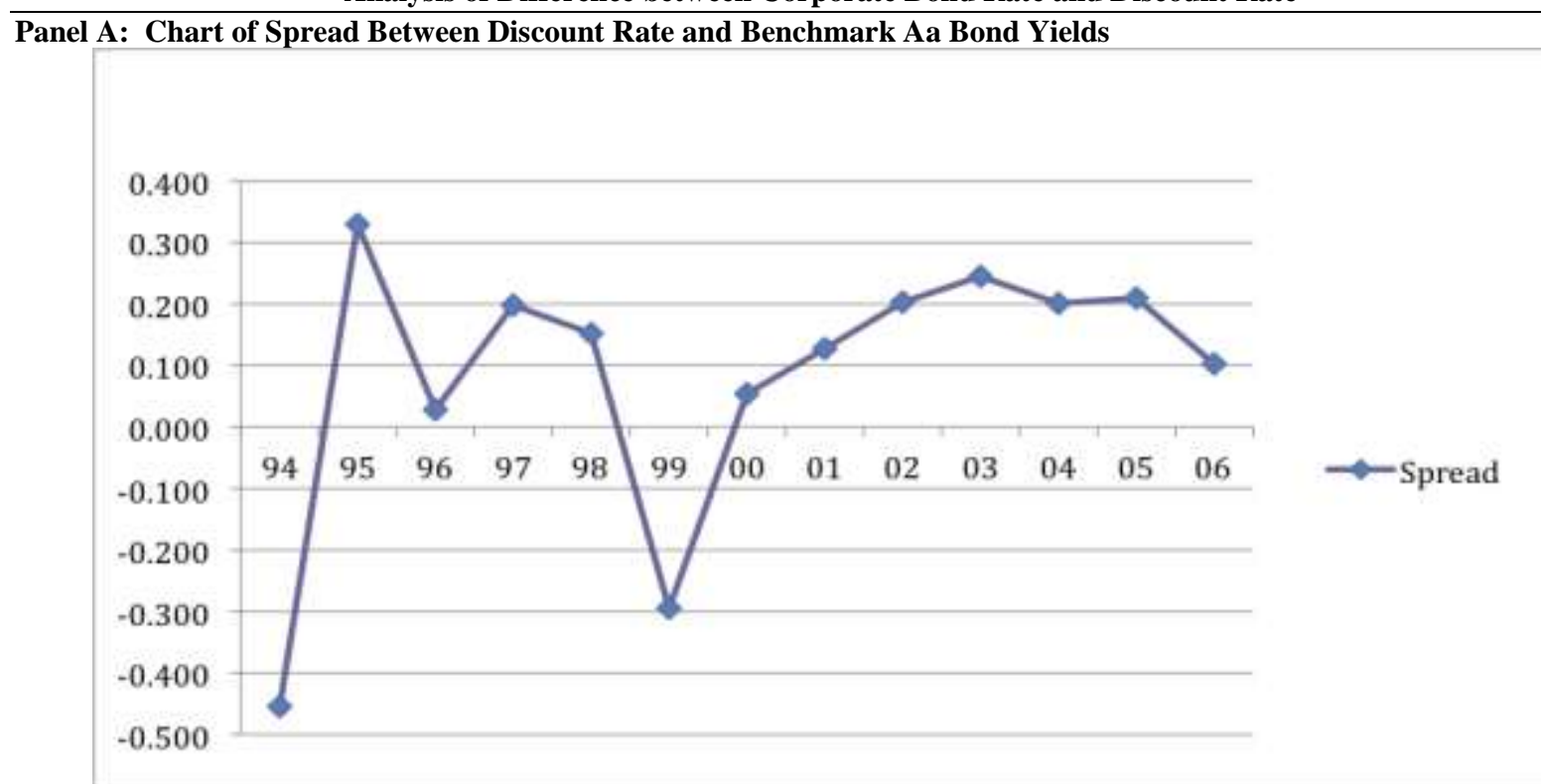

\begin{tabular}{cccccccccccccc} 
& $\mathbf{9 4}$ & $\mathbf{9 5}$ & $\mathbf{9 6}$ & $\mathbf{9 7}$ & $\mathbf{9 8}$ & $\mathbf{9 9}$ & $\mathbf{0 0}$ & $\mathbf{0 1}$ & $\mathbf{0 2}$ & $\mathbf{0 3}$ & $\mathbf{0 4}$ & $\mathbf{0 5}$ & $\mathbf{0 6}$ \\
\cline { 2 - 12 } Spread & -0.454 & 0.329 & 0.028 & 0.198 & 0.152 & -0.295 & 0.054 & 0.127 & 0.203 & 0.245 & 0.201 & 0.210 & 0.103
\end{tabular} 


\section{Panel B: Paired T-Test of Spread between Aa Corporate Rate and Discount Rate}

\begin{tabular}{cccccc}
\hline Year & $\mathbf{N}$ & Mean & StdDev & T-Stat & Pvalue \\
\hline 1994 & 490 & -0.454 & 0.547 & -18.39 & $<.0001$ \\
1995 & 490 & 0.331 & 0.477 & 15.36 & $<.0001$ \\
1996 & 490 & 0.026 & 0.352 & 1.66 & 0.097 \\
1997 & 490 & 0.196 & 0.350 & 12.36 & $<.0001$ \\
1998 & 490 & 0.153 & 0.335 & 10.12 & $<.0001$ \\
1999 & 490 & -0.295 & 0.441 & -14.81 & $<.0001$ \\
2000 & 490 & 0.054 & 0.388 & 3.09 & 0.0021 \\
2001 & 490 & 0.126 & 0.311 & 8.95 & $<.0001$ \\
2002 & 491 & 0.204 & 0.369 & 12.25 & $<.0001$ \\
2003 & 483 & 0.246 & 0.330 & 16.41 & $<.0001$ \\
2004 & 427 & 0.204 & 0.281 & 15.01 & $<.0001$ \\
2005 & 422 & 0.211 & 0.319 & 13.58 & $<.33$ \\
2006 & 382 & 0.099 & 0.307 & & $<.0001$ \\
\hline
\end{tabular}

To analyze the relationship between discount rates and corporate bond rates more closely, we graphed the spread between these rates in Figure 3, Panel A. The spread between the rates varies considerably over time, increasing over seven periods and decreasing over five periods. The spread between mean discount rates and mean Aa benchmark rates is the greatest in 2003 at nearly 25 basis points. A paired t-test on the spread between the rates for each year, presented in Panel B of Figure 3, indicates that rates are significantly different for each year except for 1996. In that year, the rates are not different at .05 or less.

\section{Discount Rate Changes}

While relative discount rate levels provide important information, they only tell half the story. It is equally important to examine how changes in the discount rate track changes in the benchmark rates. Examining changes in the rates has the advantage of mitigating firm-specific maturity differences. The levels may differ based on maturity differences, but changes in the rates would be due to exogenous factors.

Figure 4, Panel A, graphs discount rate changes against corporate bond rate changes. What is clearly noticeable is that discount rate changes track corporate bond rate changes, but tend to be smoother than corporate bond rate changes, consistent with reflecting management's desire to smooth out volatility in pension expense and liabilities. In every year but two (1998 and 2004), corporate bond rate changes are larger in magnitude than discount rate changes. This result is irrespective of whether the rates increase or decrease. Panel $\mathrm{C}$ indicates that rate changes are significantly different from each other in all years except 2004 and 2005. In sum, discount rate changes are significantly smaller than corporate bond rate changes in every year except 1998, 2004 and 2005. In 1998, the mean discount rate decline was significantly larger than the corporate rate decline, and in 2004 and 2005, the changes in rates did not differ significantly from one another.

To determine whether or not most firms were adjusting their discount rates towards the benchmark, which was also changing from period to period, we examined the size of the spread between the discount rate and the corporate rate benchmark from one year to the next. If the spread between the benchmark rate and the discount rate in, say, 2003 was greater than the spread in 2002, then we classified the firm as moving farther away from the benchmark rate, which would indicate the firm is taking a less conservative discount rate position. Conversely, if the spread between the rates declined, then we classified the firm as moving closer to the benchmark, which represents a more conservative position with respect to the firm's discount rate. 
Figure 4

Analysis of Discount Rate Changes and Corporate Bond Rate Changes

Panel A: Graph of Discount Rate and Aa Corporate Bond Yield Changes

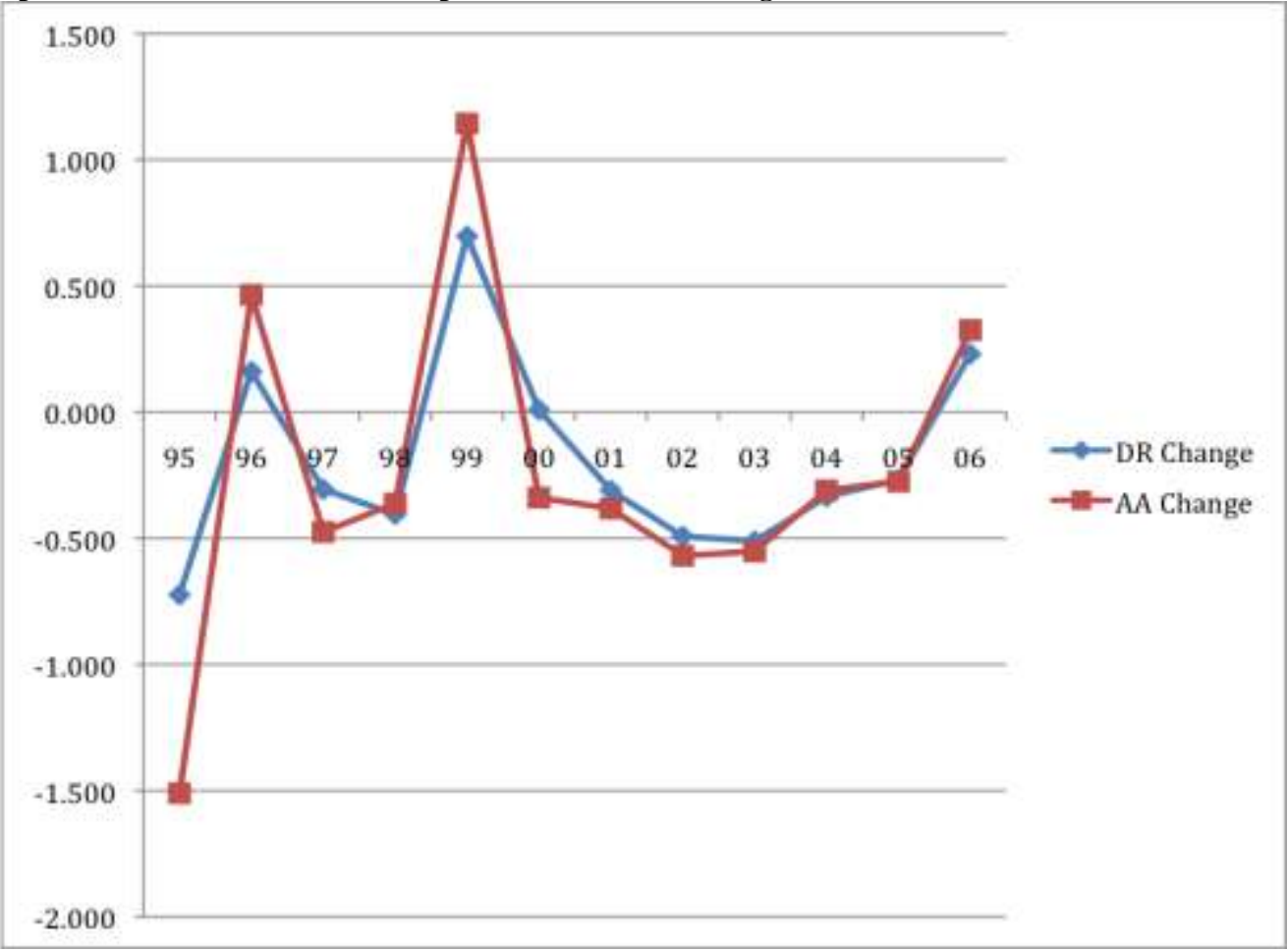

Panel B: Mean Rate Changes

$\begin{array}{lcc}\text { Year } & \text { DR Chg } & \text { AA Chg } \\ 1995 & -0.724 & -1.510 \\ 1996 & 0.161 & 0.465 \\ 1997 & -0.306 & -0.475 \\ 1998 & -0.405 & -0.362 \\ 1999 & 0.697 & 1.144 \\ 2000 & 0.009 & -0.339 \\ 2001 & -0.310 & -0.382 \\ 2002 & -0.492 & -0.569 \\ 2003 & -0.511 & -0.552 \\ 2004 & -0.335 & -0.310 \\ 2005 & -0.268 & -0.275 \\ 2006 & 0.230 & 0.325\end{array}$

Panel C: Paired T-Test of Differences between Corporate Aa Bond Yield Changes and Discount Rate Changes

\begin{tabular}{cccccc} 
Year & N & Mean & StdDev & T-Stat & P-Value \\
\hline $1994-1995$ & 490 & 0.785 & 0.719 & 24.18 & $<.0001$ \\
$1995-1996$ & 490 & -0.305 & 0.401 & -16.81 & $<.0001$ \\
$1996-1997$ & 490 & 0.169 & 0.341 & 10.96 & $<.0001$ \\
$1997-1998$ & 490 & -0.042 & 0.366 & -2.57 & 0.0105 \\
$1998-1999$ & 490 & -0.448 & 0.493 & -20.11 & $<.0001$ \\
$1999-2000$ & 490 & 0.349 & 0.470 & 16.42 & $<.0001$ \\
$2000-2001$ & 490 & 0.072 & 0.265 & 5.97 & $<.0001$ \\
$2001-2002$ & 490 & 0.078 & 0.338 & 5.13 & $<.0001$ \\
$2002-2003$ & 483 & 0.041 & 0.368 & 2.42 & 0.0157 \\
$2003-2004$ & 424 & -0.018 & 0.347 & -1.07 & 0.2852 \\
$2004-2005$ & 405 & 0.001 & 0.401 & 0.07 & 0.946 \\
$2005-2006$ & 380 & -0.097 & 0.381 & -4.95 & $<.0001$
\end{tabular}


Table 2 displays the results of the analysis. The table displays the number and percent of firms by year that changed their discount rates to increase the spread (decreasing conservatism), decrease the spread (increasing conservatism), or keep the spread the same. The table classifies the years according to whether or not the corporate rates were increasing or decreasing. In the three periods during which the corporate benchmark rates increased, $82.21 \%$ of firms' discount rates moved closer to the benchmark rates, indicating an increase in conservatism with respect to the discount rates. Since the discount rate is, on average, higher than corporate benchmark rates, these firms either increased their discount rates by less than the increase in the corporate benchmark rate or did not change their discount rates. The net effect of the observable increase in conservative rate choices in these periods is to lower the pension liability and pension expense. In contrast, over the nine periods with decreases in the corporate benchmark rate, $55.9 \%$ of the firms moved away from the benchmark rate, adopting less conservative discount rates. Again, since the discount rate is, on average, higher than corporate rates, these firms decrease their discount rate by less than the corresponding decrease in the corporate benchmark rate. In these cases, the net effect of adopting less conservative rate choices would also be to decrease the pension liability and expense.

Table 2

Effect of Increasing and Decreasing Bond Rates on

Conservatism of Discount Rate Movement Relative to the Corporate Bond Rate Benchmark*

\begin{tabular}{|c|c|c|c|c|c|c|c|}
\hline \multirow[t]{2}{*}{ Corporate Aa Yields } & \multirow[t]{2}{*}{ Year of Change } & \multicolumn{2}{|c|}{$\begin{array}{c}\text { DR Increases in } \\
\text { Conservatism }\end{array}$} & \multicolumn{2}{|c|}{$\begin{array}{c}\text { Distance Remains the } \\
\text { Same }\end{array}$} & \multicolumn{2}{|c|}{$\begin{array}{c}\text { DR Decreases in } \\
\text { Conservatism }\end{array}$} \\
\hline & & Number & Percent & Number & Percent & Number & Percent \\
\hline \multirow[t]{3}{*}{ Increasing } & $1995-1996$ & 421 & $85.74 \%$ & 3 & $0.61 \%$ & 67 & $13.65 \%$ \\
\hline & $1998-1999$ & 396 & $80.65 \%$ & 7 & $1.43 \%$ & 88 & $17.92 \%$ \\
\hline & $2005-2006$ & 394 & $80.24 \%$ & 1 & $0.20 \%$ & 96 & $19.55 \%$ \\
\hline Increasing Years Average & & & $82.21 \%$ & & $0.75 \%$ & & $17.04 \%$ \\
\hline \multirow[t]{9}{*}{ Decreasing } & $1994-1995$ & 62 & $12.63 \%$ & 3 & $0.61 \%$ & 426 & $86.76 \%$ \\
\hline & $1996-1997$ & 222 & $45.21 \%$ & 0 & $0.00 \%$ & 269 & $54.79 \%$ \\
\hline & $1997-1998$ & 233 & $47.45 \%$ & 6 & $1.22 \%$ & 252 & $51.32 \%$ \\
\hline & $1999-2000$ & 134 & $27.29 \%$ & 0 & $0.00 \%$ & 357 & $72.71 \%$ \\
\hline & $2000-2001$ & 177 & $36.05 \%$ & 1 & $0.20 \%$ & 313 & $63.75 \%$ \\
\hline & $2001-2002$ & 441 & $89.82 \%$ & 46 & $9.37 \%$ & 4 & $0.81 \%$ \\
\hline & $2002-2003$ & 27 & $5.50 \%$ & 0 & $0.00 \%$ & 464 & $94.50 \%$ \\
\hline & $2003-2004$ & 271 & $55.19 \%$ & 9 & $1.83 \%$ & 211 & $42.97 \%$ \\
\hline & $2004-2005$ & 225 & $45.82 \%$ & 92 & $18.74 \%$ & 174 & $35.44 \%$ \\
\hline $\begin{array}{l}\text { Decreasing } \\
\text { Average }\end{array}$ & & & $40.55 \%$ & & $3.55 \%$ & & $55.9 \%$ \\
\hline Overall Average & & & $50.97 \%$ & & $2.85 \%$ & & $43.94 \%$ \\
\hline Avg 1994-2001 & & & $47.85 \%$ & & $0.56 \%$ & & $51.78 \%$ \\
\hline Avg 2002-2006 & & & $55.31 \%$ & & $6.03 \%$ & & $38.65 \%$ \\
\hline
\end{tabular}

* This table compares DR movement relative to changing Aa benchmark classified according to whether the Distance between the discount rate and contemporaneous Aa bond yield decreased (increasing conservatism in the discount rate choice), stayed the same, or increased (decreasing conservatism).

In fact, however, the 2002-2005 period in which corporate benchmark rates declined appears fundamentally different than the 1994-2001 periods in which corporate benchmark rates also decline. In every year 1994-2001, a majority of firms adjusted their discount rates away from benchmark rates (becoming less conservative each year) when the benchmark rates declined. In 2002, however, nearly $90 \%$ of the sample firms moved closer to the benchmark as those benchmark rates declined (i.e., became more conservative). This is an interesting finding since this dramatic repositioning of discount rate choices occurs in the same year during which Sarbanes-Oxley became effective. Also interesting is the fact that the situation reverses in the next year. In 2003, only 5.5\% of sample firms adopted more conservative discount rate choices while $94.5 \%$ of sample firms adopted less conservative positions. During the next two years, 2004-05, a majority of firms either adopted more conservative positions or maintained the same position relative to the corporate benchmark rates. 
To further evaluate the influence of the corporate benchmark rates and time, we ran the following pooled regression model:

$\Delta$ Spread $=\beta_{0}+\beta_{1} D R_{t-1}+\beta_{2} \Delta$ AaRate $_{t-1, t}+\beta_{3 . .13}$ Year $\varepsilon$

where

$\mathrm{DR}=$ Discount Rate

$\triangle$ AaRate $_{\mathrm{t}-1, \mathrm{t}}=$ Change in Corporate Aa Bond rates from year $\mathrm{t}-1$ to year $\mathrm{t}$

$\Delta$ Spread $=\left(\mathrm{DR}_{\mathrm{t}}-\right.$ AaRate $\left._{\mathrm{t}}\right)-\left(\mathrm{DR}_{\mathrm{t}-1}-\right.$ AaRate $\left._{\mathrm{t}-1}\right)$

Year $=$ Dummy variables indicating the year from 1996 through 2006

In this model, the variable of interest is the change in the spread between the firm's discount rate choice in year $\mathrm{t}-1$ and the contemporaneous Aa corporate bond rate, and the spread in year t. Including the prior year's discount rate captures the "inertia" in the rates, and also controls for management's relative ability or inability to raise or lower the discount rate in the current period. The Aa rate change variable controls for the influence of the direction and magnitude of corporate bond rate changes on the spread. The year dummies capture the influence of the time period on the change in the spread.

Results from the regression analysis are reported in Table 3, below. The negative and significant coefficient on the prior year's discount rate suggests that the change in the spread is constrained by the earlier discount rate choice. The greater the prior year's discount rate is, the less the spread will change. The negative and significant coefficient on the Aa Rate change variable suggests that as the corporate rates increase (decrease), the spreads between the discount rate and corporate rate will decrease. This result confirms our previous observation from examining the descriptive data above.

Interestingly, while all the year dummies prove significant in the model, the coefficients for 1996 - 2001 , with the single exception of 1998, are all positive, indicating that spreads were increasing over those years. From 2002 on, the coefficient on the year dummies are uniformly negative, indicating that spreads were decreasing during those years.

Table 3

Regression Results for Rate and Time Period Influences on the Change in Observable Spread Between Firms' Discount Rates and Corporate Rate Benchmarks

\begin{tabular}{|c|c|c|c|}
\hline $\begin{array}{l}\text { Dep variable }=\Delta \text { Spread } \\
\text { Independent Variables }\end{array}$ & Coefficient & T-Stat & P-Value \\
\hline Intercept & 4.1514 & 43.03 & $<.0001$ \\
\hline $\mathrm{DR}_{\mathrm{t}-1}$ & -.5999 & -53.19 & $<.0001$ \\
\hline$\Delta$ Aa Rate R-1,t & -.9962 & -54.54 & $<.0001$ \\
\hline Year $_{96}$ & .4427 & 10.65 & $<.0001$ \\
\hline Year $_{97}$ & .0762 & 2.77 & 0.0057 \\
\hline Year $_{98}$ & -.2067 & -6.91 & $<.0001$ \\
\hline Year $_{99}$ & .6461 & 11.97 & $<.0001$ \\
\hline Year $_{00}$ & .3827 & 13.05 & $<.0001$ \\
\hline Year $_{01}$ & .0686 & 2.39 & 0.0169 \\
\hline Year $_{02}$ & -.2981 & -10.87 & $<.0001$ \\
\hline Year $_{03}$ & -.6117 & -20.31 & $<.0001$ \\
\hline Year $_{04}$ & -.7565 & -20.82 & $<.0001$ \\
\hline Year $_{05}$ & -.8895 & -22.64 & $<.0001$ \\
\hline Year $_{06}$ & -.5614 & -11.61 & $<.0001$ \\
\hline $\operatorname{Adj} R^{2}$ & .6738 & & \\
\hline
\end{tabular}


Where,

$\begin{array}{ll}\Delta \text { Spread } & =\left(\mathrm{DR}_{\mathrm{t}}-\text { AaRate }_{\mathrm{t}}\right)-\left(\mathrm{DR}_{\mathrm{t}-1}-\text { AaRate }_{\mathrm{t}-1}\right) \\ \mathrm{DR}_{\mathrm{t}-1} & =\text { Discount rate at time } \mathrm{t} \\ \Delta \text { Aa Rate }_{\mathrm{t}, \mathrm{t}-1} & =\text { Change in Aa Bond Yields from time } \mathrm{t}-1 \text { to } \mathrm{t} \\ \text { Year }_{\mathrm{t}} & =\text { Indicator variable for year } \mathrm{t} \text {, denoted by the subscript }\end{array}$

To summarize, the evidence from our analysis shows that discount rates are adjusted frequently as required by SFAS 87. Nevertheless, the magnitude of discount rate adjustments is generally less than corporate bond rate changes, suggesting that managers smooth out the impact on the financials and pension disclosures. Further, it appears that in the early years of this study, discount rates are especially sticky when corporate bond rates decline, and less so when rates increase; however, since 2002, firms have moved closer to benchmarks even though benchmark rates declined, indicating that discount rates declined by a greater magnitude in these periods than corporate rates did. This observation is consistent with firms responding to pressure to reflect benchmark rates more fully after keeping rates too high during the recession and interest rate decline in the early 2000s.

\section{ANALYSIS OF THE EXPECTED RATE OF RETURN}

Of the reported pension rates, the expected rate of return has, perhaps, attracted the most attention within the popular business press because the rate is relatively easy to understand and to compare to current investment returns. When firms show losses on their pension assets, and yet still report expected rates of return at close to 9\%, it is easy to believe that managers of these firms are using high expected returns to reduce pension expense without regard to the quality of the estimate. In other words, management may be taking undue advantage of the smoothing mechanisms built into SFAS 87 in order to increase earnings. In fact, Warren Buffett (2001) has suggested that firms have irresponsibly kept expected rates of return too high and are likely to face litigation unless they reduce those rates.

SFAS 87 states that the expected rate of return "shall reflect the average rate of earnings expected on the funds invested or to be invested," and that managers, in estimating the rate, should give "appropriate consideration ... to the returns being earned by the plan assets in the fund and the rates of return expected to be available for reinvestment" (SFAS 87, paragraph 45). While management should consider the past returns, they should also consider the expected reinvestment rates of return available in the future.

In order to assess the expected return empirically, we compared the rate to two firm-specific benchmarks. The first is the simple, unadjusted actual return, calculated as the firm's actual dollar return divided by the average plan assets for each year, specified below:

$$
A R R_{t}=\frac{\text { Actual Return }_{t}}{\left(\text { Plan Assets }_{t}+\text { Plan Assets }_{t-1}\right) / 2}
$$

This rate is unadjusted for firm contributions or benefit payments, or for any of the other items that may affect the plan assets during a given year. ${ }^{15}$ While this rate has the advantage of simplicity, it is a short-run return calculation, since it captures only the year-to-year returns.

Our second benchmark is a calculation of the internal rate of return earned on plan assets from 1994 (year $t$ ) through each period (year $\mathrm{t}+\mathrm{n}$ ). It considers additional cash flows to or from the plan in each period. This measure represents the rate of return that sets beginning plan assets equal to ending plan assets for each period, including the effect of other cash inflows and outflows. Since each period's rate represents the rate earned from year $t$ to year $t+n$,

\footnotetext{
${ }^{15}$ From one year to the next, pension plan assets may be affected by foreign currency translations, acquisitions and divestitures, settlements, firm contributions, participant contributions, benefit payments, transfers, and administrative expenses, as well as gains or losses.
} 
the rate begins to reflect the actual, long-run rate of return earned on plan assets as year $t+n$ moves further away from year t. Conceptually, this is the rate that managers might choose as the expected return if they were to have perfect information concerning future returns and other cash flows affecting the plan. We calculate the internal rate of return as follows:

$$
P A_{t+n}=P A_{t}\left(1+\frac{i}{2}\right)^{2 n}+N C\left(1+\frac{i}{2}\right)^{2 n-.5}+N C\left(1+\frac{i}{2}\right)^{2 n-1.5} \ldots N C\left(1+\frac{i}{2}\right)^{2 n-15.5}
$$

Where,

PA $\quad=$ Fair value of plan assets

$\mathrm{NC} \quad=$ Net cash flow to the plan, including contributions and benefit payments and any other cash flows affecting the plan in any given year

$\mathrm{i} \quad=$ Internal rate of return

To determine the internal rate of return (i), we assumed that all cash flows affecting the plan occurred at the mid-point of each year. For example, to determine the internal rate of return from 1994-2006, we set ending plan assets in 2006 equal to the ending plan assets in 1994 plus or minus the net cash flows occurring each year from mid-1995-mid-2006. We then solved equation 2 for i. This rate, then, represents the long-run, actual rate of return on plan assets from 1994-2006.

Figure 5 charts mean expected rates of return against both the simple average actual rate of return and the mean internal rate of return. As we noted earlier, the mean expected rate of return appears relatively stable, ranging from a peak of $9.00 \%$ in 2000 to a low of $8.14 \%$ in 2006, a spread of only 86 basis points over 13 years, with all of the downward movement occurring since 2000. On the other hand, the average actual rate of return displays much more variability, as might be expected of year-to-year returns.

From 1995-1999, the simple, annual returns are quite high, ranging from a high of $16.54 \%$ in 1995 to a low of $10.94 \%$ in 1998 . In 2000 , the average return was $4.93 \%$, but then drops precipitously to an average loss of over 5\% for both 2001 and 2002, recovering in 2003 with an average return of 10.27\% and a return of $10.18 \%$ in 2004 . With the exception of the delining market period, from 2000-2002, the expected rates of return are lower than the simple, actual rates of return each year. The 12-period mean of these annual returns is $8.345 \%$, which is consistent with the reported expected rates.

While these actual returns are useful in providing a simple benchmark with which to compare expected rates of return, they fail to consider the additional cash flows affecting the plans, so they may be inaccurate, depending on the nature and magnitude of the additional cash flows. In addition, they represent short-run returns; averaging the returns over a long period of time might mitigate this aspect to a certain extent, but even that represents a simple, unweighted average. More recent returns would reflect current asset allocations, so they may be more indicative of rates expected to be available for reinvestment. While they may be a more appropriate guide to pension expected rates of return than a simple average, determining an appropriate weighting of past returns is problematic. There is no theory or conceptual basis to prefer one weighting scheme over another; any weighting method applied would necessarily be ad hoc.

To overcome this problem, we derived the internal rate of return (IRR) for each firm for each period as described above, then took the average IRR for our sample and used this as a benchmark with which to compare expected rates of return. Figure 5 shows that, in general, the average IRR of pension plan returns has been decreasing over the 1995-2003 time period, stable between 2004-05, and slightly increasing from 2005- 2006. The range runs from a high of $17.39 \%$ in 1995 to a low of $8.01 \%$ in 2002. The 1995 IRR represents, however, only a one-year return. While a one-year return is a poor proxy for the long-run rate, the IRRs begin to reflect a long-run return as we move farther from 1995, which suggests that the decline in rates we observe is really a progression to a long-run return. An advantage of the IRR is that the rate is based on actual events that have occurred and not management expectations, which cannot be verified. Over the period during which firms were suffering substantial 
losses in their pension plan investments (2001 and 2002 - a 7 and 8 year IRR, respectively), the long run IRR was $10.03 \%$ (2001) and 8.01\% (2002). It appears that, over the long run, firms' actual rates of return on pension plan assets are close to their expected rates of return, but that in 2002, as the market losses get impounded into the actual returns, expected rates slightly overstate long-run actual returns on pension investments.

Figure 5

Analysis of Mean Expected Rates of Return Against Mean Actual Return Benchmarks

Panel A: Chart of Returns

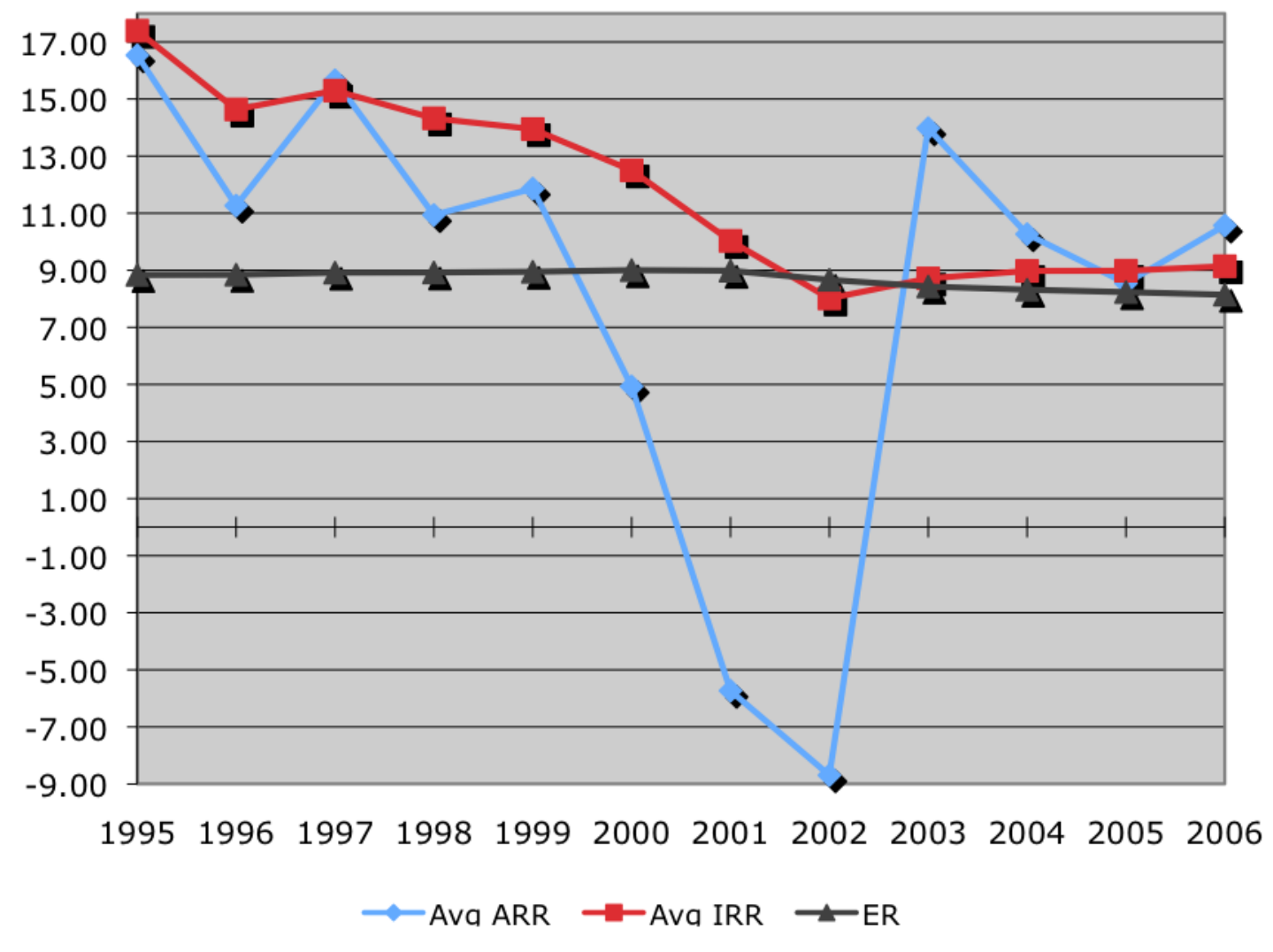

Panel B: Table of Return Values

\begin{tabular}{cccc} 
Year & Simple Average Actual Rate of Return & Average Internal Rate of Return & Expected Rate of Return \\
\hline 1995 & 16.54 & 17.39 & 8.84 \\
1996 & 11.27 & 14.63 & 8.85 \\
1997 & 15.66 & 15.30 & 8.92 \\
1998 & 10.94 & 14.32 & 8.92 \\
1999 & 11.86 & 13.95 & 8.95 \\
2000 & 4.93 & 12.50 & 9.00 \\
2001 & -5.73 & 10.03 & 8.98 \\
2002 & -8.69 & 8.01 & 8.67 \\
2003 & 13.98 & 8.71 & 8.43 \\
2004 & 10.27 & 8.98 & 8.32 \\
2005 & 8.54 & 8.98 & 8.24 \\
2006 & 10.57 & 9.14 & 8.14 \\
\hline
\end{tabular}


To examine the extent of compliance of firms within our sample, we performed a number of more detailed tests. Table 4 presents the distribution of firms' internal rates of return by decile. For each decile, we determine the average expected rate of return (ERR) for the firms within that decile. For firms in the lowest decile, the average IRR was under $4.62 \%$ each year, yet the average expected rate was $8 \%$ or higher each year until 2006 , when it was $7.96 \%$. Beginning in 2001, the number of deciles having lower IRRs than expected rates begins to increase. By 2002, the average expected return for the first six deciles have lower long-run internal rates of return than expected rates of return.

Table 4

Analysis of Distribution of Internal Rates of Return by Decile

\begin{tabular}{|c|c|c|c|c|c|c|c|c|}
\hline \multirow[b]{2}{*}{ Decile } & \multicolumn{2}{|c|}{1995} & \multicolumn{2}{|c|}{1996} & \multicolumn{2}{|c|}{1997} & \multicolumn{2}{|c|}{1998} \\
\hline & $\begin{array}{c}\text { Avg } \\
\text { IRR\% }\end{array}$ & $\begin{array}{c}\text { Avg } \\
\text { ERR\% }\end{array}$ & $\begin{array}{c}\text { Avg } \\
\text { IRR\% }\end{array}$ & Avg ERR\% & $\begin{array}{c}\text { Avg } \\
\text { IRR\% }\end{array}$ & Avg ERR\% & $\begin{array}{c}\text { Avg } \\
\text { IRR\% }\end{array}$ & $\begin{array}{c}\text { Avg } \\
\text { ERR\% }\end{array}$ \\
\hline $1^{\text {st }}$ Decile & -0.95 & 8.67 & 1.18 & 8.60 & 1.95 & 8.64 & 2.88 & 8.41 \\
\hline $2^{\text {nd }}$ Decile & 8.81 & 8.67 & 9.87 & 8.69 & 10.48 & 8.68 & 10.34 & 8.82 \\
\hline $3^{\text {rd }}$ Decile & 13.15 & 8.82 & 12.23 & 8.82 & 13.34 & 8.80 & 12.53 & 8.76 \\
\hline $4^{\text {th }}$ Decile & 16.11 & 8.82 & 13.93 & 8.67 & 14.94 & 8.93 & 13.55 & 9.05 \\
\hline $5^{\text {th }}$ Decile & 18.27 & 8.77 & 15.19 & 8.92 & 16.22 & 8.82 & 14.83 & 8.91 \\
\hline $6^{\text {th }}$ Decile & 19.88 & 8.73 & 16.41 & 8.86 & 17.08 & 8.99 & 15.71 & 9.15 \\
\hline $7^{\text {th }}$ Decile & 21.46 & 9.02 & 17.31 & 9.04 & 17.86 & 8.93 & 16.52 & 8.89 \\
\hline $8^{\text {th }}$ Decile & 23.09 & 8.79 & 18.19 & 9.05 & 18.54 & 9.28 & 17.44 & 9.08 \\
\hline $9^{\text {th }}$ Decile & 24.64 & 8.97 & 19.31 & 8.89 & 19.65 & 9.11 & 18.27 & 9.15 \\
\hline $10^{\text {th }}$ Decile & 28.99 & 9.08 & 22.38 & 8.88 & 22.58 & 8.99 & 20.89 & 9.01 \\
\hline \multirow[t]{3}{*}{ Correl Coeff } & & .765 & & .754 & & .772 & & .859 \\
\hline & \multicolumn{2}{|c|}{1999} & \multicolumn{2}{|c|}{2000} & \multicolumn{2}{|c|}{2001} & \multicolumn{2}{|c|}{2002} \\
\hline & $\begin{array}{c}\text { Avg } \\
\text { IRR\% }\end{array}$ & $\begin{array}{c}\text { Avg } \\
\text { ERR\% } \\
\end{array}$ & $\begin{array}{c}\text { Avg } \\
\text { IRR\% }\end{array}$ & $\begin{array}{c}\text { Avg } \\
\text { ERR\% } \\
\end{array}$ & $\begin{array}{c}\text { Avg } \\
\text { IRR\% }\end{array}$ & $\begin{array}{c}\text { Avg } \\
\text { ERR\% }\end{array}$ & $\begin{array}{c}\text { Avg } \\
\text { IRR\% }\end{array}$ & $\begin{array}{c}\text { Avg } \\
\text { ERR\% } \\
\end{array}$ \\
\hline $1^{\text {st }}$ Decile & 4.34 & 8.48 & 4.49 & 8.56 & 2.61 & 8.84 & 1.98 & 8.52 \\
\hline $2^{\text {nd }}$ Decile & 10.16 & 8.82 & 9.30 & 8.82 & 7.11 & 8.77 & 4.99 & 8.52 \\
\hline $3^{\text {rd }}$ Decile & 12.04 & 9.02 & 10.91 & 8.80 & 8.41 & 8.80 & 6.22 & 8.29 \\
\hline $4^{\text {th }}$ Decile & 13.08 & 8.78 & 11.94 & 8.89 & 9.29 & 8.77 & 7.09 & 8.59 \\
\hline $5^{\text {th }}$ Decile & 14.23 & 9.09 & 12.67 & 9.06 & 10.20 & 9.01 & 7.91 & 8.86 \\
\hline $6^{\text {th }}$ Decile & 14.99 & 9.11 & 13.38 & 9.23 & 10.86 & 9.09 & 8.56 & 8.71 \\
\hline $7^{\text {th }}$ Decile & 15.69 & 8.98 & 14.06 & 9.09 & 11.48 & 9.13 & 9.25 & 8.85 \\
\hline $8^{\text {th }}$ Decile & 16.71 & 9.13 & 14.72 & 9.25 & 12.13 & 9.25 & 9.98 & 8.87 \\
\hline $9^{\text {th }}$ Decile & 17.69 & 8.94 & 15.57 & 9.13 & 12.81 & 9.17 & 10.80 & 8.66 \\
\hline $10^{\text {th }}$ Decile & 20.28 & 9.21 & 17.75 & 9.20 & 15.40 & 9.01 & 13.15 & 8.74 \\
\hline \multirow[t]{3}{*}{ Correl Coeff } & & .859 & & .909 & & .645 & & .588 \\
\hline & \multicolumn{2}{|c|}{2003} & \multicolumn{2}{|c|}{2004} & \multicolumn{2}{|c|}{2005} & \multicolumn{2}{|c|}{2006} \\
\hline & $\begin{array}{c}\text { Avg } \\
\text { IRR\% }\end{array}$ & $\begin{array}{c}\text { Avg } \\
\text { ERR\% }\end{array}$ & $\begin{array}{c}\text { Avg } \\
\text { IRR\% }\end{array}$ & $\begin{array}{c}\text { Avg } \\
\text { ERR\% }\end{array}$ & $\begin{array}{c}\text { Avg } \\
\text { IRR\% }\end{array}$ & $\begin{array}{c}\text { Avg } \\
\text { ERR\% }\end{array}$ & $\begin{array}{c}\text { Avg } \\
\text { IRR\% }\end{array}$ & $\begin{array}{c}\text { Avg } \\
\text { ERR\% }\end{array}$ \\
\hline $1^{\text {st }}$ Decile & 3.29 & 8.24 & 4.16 & 8.10 & 4.36 & 8.06 & 4.62 & 7.96 \\
\hline $2^{\text {nd }}$ Decile & 6.07 & 8.22 & 6.66 & 8.12 & 6.94 & 8.19 & 7.20 & 8.09 \\
\hline $3^{\text {rd }}$ Decile & 7.18 & 8.44 & 7.59 & 8.28 & 7.66 & 8.13 & 7.96 & 8.05 \\
\hline $4^{\text {th }}$ Decile & 7.95 & 8.39 & 8.22 & 8.30 & 8.31 & 8.20 & 8.54 & 8.10 \\
\hline $5^{\text {th }}$ Decile & 8.64 & 8.32 & 8.90 & 8.25 & 8.91 & 8.21 & 9.10 & 8.19 \\
\hline $6^{\text {th }}$ Decile & 9.28 & 8.44 & 9.43 & 8.43 & 9.39 & 8.32 & 9.55 & 8.07 \\
\hline $7^{\text {th }}$ Decile & 9.83 & 8.49 & 9.92 & 8.41 & 9.87 & 8.35 & 9.98 & 8.27 \\
\hline $8^{\text {th }}$ Decile & 10.50 & 8.54 & 10.52 & 8.49 & 10.39 & 8.40 & 10.52 & 8.23 \\
\hline $9^{\text {th }}$ Decile & 11.24 & 8.53 & 11.10 & 8.45 & 10.99 & 8.42 & 11.08 & 8.39 \\
\hline $10^{\text {th }}$ Decile & 13.48 & 8.47 & 13.07 & 8.30 & 12.83 & 8.23 & 12.70 & 8.15 \\
\hline Correl Coeff & & .797 & & .733 & & .718 & & .707 \\
\hline
\end{tabular}


Descriptively, it appears that firms generally have actual returns on their pension assets in line with their expected returns, but that market conditions deteriorated so much by 2002 that in that year, the majority of firms had expected rates of return that overstated their long-run experience. This fact may explain why we observe a large jump in the number of firms changing their expected rates of return after 2001 (Table1); the data also suggest, however, that the observable reductions may not have been quite enough for a large number of firms since Table 4 indicates that $40 \%$ of the firms still had long-run internal rates of return lower than expected returns in both 2003 and 2004, and 30\% of the firms had lower long-run IRRs in 2005 and 2006 than their reported expected rates of return.

Underscoring this observation, the correlation between the average IRR and ERR for the deciles increases each year from 1995 until 2000, when it reaches .91. ${ }^{16}$ The correlation drops to only .645 in 2001 and .588 in 2002. The correlation improves for 2003 - 2006, but does not approach the values for 1998 - 2000. The evidence suggests that prior to 2001, there was a relatively strong correlation between the magnitude of actual returns and the magnitude of the expected rates. Generally speaking, firms with higher internal rates of return set higher expected rates. This correlation weakens considerably in 2001 and 2002, during the two weakest recessionary years in the test period.

Table 5

Analysis of the Relationship Between Internal Rates of Return and Expected Rates of Return

\begin{tabular}{ccc}
\hline Panel A: Number and percent of firms with Cumulative IRRs Less than Expected Rates of Return \\
\hline Year & Num of Firms & \% of Firms \\
\hline 1995 & 74 & $15.35 \%$ \\
1996 & 55 & $11.41 \%$ \\
1997 & 50 & $10.37 \%$ \\
1998 & 51 & $10.58 \%$ \\
1999 & 45 & $9.34 \%$ \\
2000 & 60 & $12.45 \%$ \\
2001 & 148 & $30.83 \%$ \\
2002 & 272 & $57.51 \%$ \\
2003 & 188 & $41.05 \%$ \\
2004 & 142 & $34.38 \%$ \\
2005 & 130 & $32.58 \%$ \\
\hline
\end{tabular}

Panel B: Number of Years Expected Rate of Return is Greater than Cumulative IRR

\begin{tabular}{ccc}
\hline Num of Years ERR $>$ Cum IRR & Num of Firms & \% of Firms \\
\hline 0 & 183 & $37.27 \%$ \\
1 & 91 & $18.53 \%$ \\
2 & 36 & $7.33 \%$ \\
3 & 25 & $5.09 \%$ \\
4 & 21 & $4.28 \%$ \\
5 & 31 & $6.31 \%$ \\
6 & 38 & $7.74 \%$ \\
7 & 15 & $3.05 \%$ \\
8 & 17 & $3.46 \%$ \\
9 & 5 & $1.02 \%$ \\
10 & 9 & $1.83 \%$ \\
11 & 6 & $1.22 \%$ \\
\hline
\end{tabular}

*IRR = Internal Rate of Return from 1994 through each year listed

\footnotetext{
${ }^{16}$ The increase in correlation coefficients from 1995-2000 may be due to the fact that the IRR calculation includes successively more years, and thus becomes a better measure of the long-run actual return.
} 
Table 5 (Panel A) examines the number and percent of firms having internal rates of return lower than expected rates of return for each year. For the four-year period 1996-1999, the percentage of firms having internal rates of return lower than their expected rates was fairly stable, ranging between $9.3-11.4 \%$; that is, from 45 to 55 firms each year had internal rates of return than did not necessarily justify the higher expected rates. In 2000, the number (percent) of firms in this condition begins to increase: 60 (12.5\%) in 2000, 148 (30.83\%) in 2001, and 272 $(57.5 \%)$ in 2002. In 2003, the number (percent) of firms in this condition drops to $188(41.1 \%)$, and then declines to $100(27.17 \%)$ by 2006 . These data indicate that a fairly large sub-sample of our firms (up to $58 \%$ ) found themselves in the position of having internal rates of return lower than expected rates of return on pension assets at least once during our test period. If a firm's IRR fell beneath its expected return only once or twice during the period, then it is likely that its expected return remains a reasonable assumption. On the other hand, if a firm had annual IRRs that were rarely equal to its expected rate of return during the test period, then it seems likely that their expected rates were not justified by their long-run actual returns. Panel B of Table 5 provides this data.

Panel B indicates that 14 firms (2.85\%) had lower internal rates of return on pension assets than expected rates all twelve periods. Combining all the firms whose actual returns were lower than their expected returns for six or more years, we find that approximately $21.2 \%$ (104) of the sample firms were in this condition. 135 (27.5\%) firms had expected rates of return greater than their internal rates of return on pension assets would justify for five or more years. On the other hand, 356 firms $(72.5 \%)$ had expected rates of return greater than their internal rates of return for four (or fewer) of the 12 periods. On this basis, their internal rates of return justified the expected rate of return assumptions, for most, if not all, of the test period.

\section{CONCLUSION}

The pension rate estimates that firms use to determine pension expense and liability amounts are important because they have a material impact not only on the pension disclosures, but because they may also indirectly impact the income statement and balance sheets of the firm. Articles in the popular business press periodically allege that management uses these rates to influence reported earnings, or to reduce liability exposure, or to affect pension funding amounts or metrics. This paper examines the estimates firms use to account for their pension plans and compares both the discount rate and expected rate of return to benchmarks based on the authoritative literature and economic theory.

The results suggest that firms' discount rates correspond most closely to a benchmark consisting of the rates on a portfolio of high quality, corporate bonds rather than rates published by the Pension Benefit Guaranty Corporation or by rates on 20-year treasury bills. Discount rates tend to track corporate bond rates closely, but we found that they are usually higher than contemporaneous bond rates. In all but two periods (1994 \& 1999), discount rates were significantly higher than benchmark rates. In addition, changes in discount rates were smaller than changes in corporate rates, suggesting that the discount rates, while revised in compliance with SFAS 87, are revised in a manner that reduces the volatility inherent in corporate bond rates, and thus have a smoothing impact on reported pension amounts. Interestingly, we also found that when corporate bond rates fell, corresponding discount rate changes (declines) were lower than when corporate bond rates rose. Finally, we found that during 2001 and 2002, both corporate rates and discount rates declined, but in both periods, discount rates declined much less than corporate rates declined. This evidence suggests that managers revised their rates according to the requirements of SFAS 87, but that the revisions are smoother than revisions which might be appropriate based on a stricter adherence to the benchmark. It also appears that managers were affected by the poor economic conditions prevailing from 2001-2002 and were hesitant to revise discount rates downward as much as the economic conditions warranted.

Results of our expected rate of return analysis indicate that, on average, actual long-run returns seem to justify the use of the expected rates of return we observe. This is particularly true prior to 2002. In 2002, average IRRs fell beneath average expected returns, so expected rates were be slightly higher than historical long-run returns would support. In addition, we found that during the recessionary years of 2001 and 2002, the number of firms whose expected returns were higher than their long-run IRRs increased to close to $60 \%$ of our sample. Finally, we observed a large minority of firms (about 27\%) reporting expected rates of return that were not supported or justified by their internal rates of return. 
Since we studied managers' pension rate choices over a relatively extended time frame, our findings may prove useful to the FASB as it considers the second phase of its current pension project. We have provided some evidence that while pension rates generally reflect benchmarks, they tend to have a smoothing effect relative to benchmarks and also tend to lag benchmark adjustments during extreme economic downturns. Our findings lend support to the requirement in SFAS 132R to provide a narrative description of the reasonableness and basis for the expected rate of return assumption, and also suggest that the Board's consideration of sensitivity analysis for pension rates during the second phase of its current pension project may be warranted.

\section{AUTHOR INFORMATION}

Dr. Alan Blankley is an Associate Professor of Accounting in the Belk College of Business at the University of North Carolina at Charlotte. He received his Ph.D. in Accounting from Texas A\&M University. He has over 30 publications in journals such as Accounting Horizons, the Journal of Information Systems, the Journal of Derivatives, and Journal of Business Logistics. He has also worked as a consultant for OnForce, Hewlett-Packard, Multimedia Marketing Group, and Wachovia Securities.

Dr. Philip G. Cottell is a Professor of Accounting at the Richard T. Farmer School of Business at Miami University. He received his Ph.D. in Accounting from the University of Kentucky. Dr. Cottell teachers financial accounting and is a nationally known expert in problem-based learning.

Dr. David Hurtt is an associate professor in the Hankamer School of Business at Baylor University. His primary teaching and research areas are in financial accounting. Dr. Hurtt has published in leading accounting journals including the Accounting Review and the Journal of Accounting and Economics. He earned his Ph.D. at Texas A\&M University.

\section{REFERENCES}

1. Alster, A. 1993. Dark lining to a silver cloud. Forbes (November): 137-138.

2. Amir, E. and S. Benartzi. 1998. The expected rate of return on pension funds and asset allocation as predictors of portfolio performance. Accounting Review, 73, (July): 335-352.

3. Anders, G. 1992. Pension fund managers face a moment of truth as interest rates plunge and equities stagnate. The Wall Street Journal (October 5): C1, C13

4. Blankley, A. I. and E. P Swanson. 1995. A longitudinal study of SFAS 87 pension rate assumptions. Accounting Horizons (December): 1-21.

5. Brown, K. and J. Weil. 2001. Lift's off: Pension costs threaten earnings, The Wall Street Journal (November 13): C1-C2

6. Buffet, W. 2001. Warren Buffet on the stock market. Fortune (December 10): 40-46.

7. Bulkeley, W. 2002. IBM's overfunded pension plan won't pump up bottom line as much this year as it has in past, The Wall Street Journal (March 15).

8. Carlson, C. 2002. Mind games: How companies use assets in pension plans to boost profits and trick investors. Bloomberg Personal Finance (November): 29-32.

9. Deloitte \& Touche. 2003. 2003 Survey of economic assumptions used for SFAS no. 87 and SFAS no. 106 purposes.

10. Financial Accounting Standards Board. 1985. Employer's accounting for pensions. Statement of Financial Accounting Standards no. 87. Norwalk, CT: FASB.

11. 1990. Employer's accounting for postretirement benefits other than pensions. Statement of Financial Accounting Standards no. 106. Norwalk, CT: FASB.

12. 2003. Employer's disclosures about pensions and other postretirement benefits - an amendment of FASB statements No. 87, 88, and 106. Statement of Financial Accounting Standards no. 132 (Revised 2003). Norwalk, CT: FASB.

13. 2006. Employer's accounting for defined benefit pension and other postretirement plans-an amendment of FASB statements No. 87, 88, 106, and 132(R). Statement of Financial Accounting Standards no. 158. Norwalk, CT: FASB.

14. Frederick, J. 2002. The trouble with earnings, Money (March): 72-76. 
15. Government Accounting Office. 2004. Private pensions: Publicly available reports provide useful but limited information on plan's financial condition, Report to the Ranking Minority Member, Committee on Education and the Workforce, House of Representatives (March): 1-43.

16. Krantz, M. 2002. Flap exposes tricks of accounting trade, USA Today (February 11).

17. Laise, E. 2002. Fuzzy math. Smart Money (July): 27.

18. Light, L. 1993. Many unhappy returns: Rock bottom rates have some pension funds short on reserves. Business Week (May 31): 76-77.

19. Mahar, M. 2004. BULL! A History of the Boom and Bust, 1882-2004. Harper Business, New York, N.Y.

20. $\quad$ PBGC 2004. Pension Benefit Guaranty Corporation: Performance and accountability report. Fiscal Year 2004 (November 15).

21. Pulliam, S. 1993a. Aggressive rate assumptions put pension funds at risk. The Wall Street Journal (March 25): C1, C21.

22. 1993b. Retirees at risk: Hopeful assumptions let firms minimize pension contributions. The Wall Street Journal (September 2): A1, A6.

23. Reilly, D. 2006. For GM, Pension-Accounting Shift Could Dwarf Gain on GMAC Deal. Wall Street Journal (April 5): C3.

24. Schultz, E. E. and T. Francis. 2004. How Lucent's retiree programs cost it zero, even yielded profit. Wall Street Journal (March 29): 1.

25. Securities and Exchange Commission. 2005. Current accounting and disclosure issues in the Division of corporation finance. (March 4). Section H.1.

http://www.sec.gov/divisions/corpfin/acctdis030405.htm\#P529 85472

26. Solomon, D. and L. Hawkins, Jr. 2005. Small changes in calculations at companies have a big effect on retiree liability - and profit, Wall Street Journal (November 9): C1. 